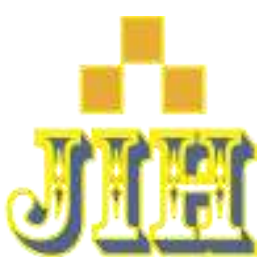

\title{
Peranan Etnis Tionghoa Muslim Pada Masa Kolonial Belanda Abad Ke-19 Di Palembang
}

\author{
Wela Celsi Anggela \\ Program Studi Sejarah Peradaban Islam \\ UIN Sunan Kalijaga Yogyakarta \\ welacelsi@gmail.com
}

\begin{tabular}{|c|c|c|}
\hline Submited: & Revision Required: & Published: \\
13 April 2021 & 19 Mei 2021 & 15 Juni 2021 \\
\hline
\end{tabular}

\begin{abstract}
This Study describes the historical series of the role of the Chinese Muslim etnich group in the 19th century Dutch colonial period in Palembang, in this article will reveal several Chinese Muslim ethnich figures and clerics who played a role in the 19th century Dutch colonial period in Palembang, including; Kiyai Mas Husin (Yu-Chien), Baba Yu Chien has a son named Muhammad Najib I who holds the title of Kiyai Demang Jayosepuh Wiraguno who served as a minister during the reign of Sultan Ahmad Najamuddin, Baba Balqiyah and Baba Mas'ud, they played a role in resisting the Dutch colonial and drowning Dutch cruise ship at the mouth of the Ogan river in Palembang. After they died, his role was replaced by Baba Muhammad Najib II or Kiyai Demang Jayalaksana who was an important figure in the construction of the Great Mosque of Palembang in the reign of Sultan Muhammad Badaruddin II $(1724 \mathrm{M} / 1137 \mathrm{H})$. The majority are Muslims from the Dutch colonial nation.
\end{abstract}

Keywords: muslim chinese, ulama, dutch sultanate, palembang.

\footnotetext{
Abstrak

Penelitian ini mendeskripsikan rangkaian sejarah dari peranan Etnis Tionghoa Muslim pada masa Kolonial Belanda abad ke-19 di
} 
Palembang. Dalam artikel ini akan mengungkapkan beberapa tokoh maupun ulama Etnis Tionghoa Muslim yang berperan pada masa Kolonial Belandaabad ke-19 di Palembang antara lain: Kiyai Mas Husin (Yu-Chien), Baba Yu-Chien kemudian memiliki anak bernama Muham mad Najib I yang bergelar Kiyai Demang Jayosepuh Wiraguno yang menjabat sebagai menteripada masa Sultan Ahmad Najamuddin, Baba Balqiyah dan Baba Mas'ud, mereka ikut berperan dalam melawan Kolonial Belanda dan menenggelamkan kapal pesiarmilik Belanda di Muara Sungai Ogan Palembang. Setelah mereka meninggal digantikanlah perannya oleh Baba Muhammad Najib II atau Kiyai Demang Jayalaksana yang merupakan tokoh penting dalam pembangunan masjid Agung Palembang di masa Sultan Mahmud Badaruddin II (1724 M/ $1137 \mathrm{H})$ beliau memotori pencetakan Al-Quran secara Massal. Tujuannya untuk menjaga jati diri bangsa Melayu yang mayoritas Islam dari bangsa penjajah Belanda.

Kata Kunci: etnis tionghoa muslim, ulama, belanda, kesultanan, Palembang

\section{PENDAHULUAN}

Palem bang memiliki letak wilayah yang sangat strategis sebagai tujuan perdagangan di Nusantara pada abad 16 sampai abad $20 \mathrm{M}$, terjadi arus imigrasi orang Tionghoa dari negeri Tiongkok sampai di Palem bang. Akibat migrasi tersebut, banyak orang yang memilih untuk tinggal dan menetap di Palembang, dan mayoritas etnis Tionghoa di Palem bang berperan sebagai pedagang (Afthonul Afif, 2012: 70).

Bermigrasinya orang-orang Tionghoa ke Palembang berhubungan erat dengan jalur pelayaran tradisional yang sangat bergantung pada hembusan angin muson. Rute perjalanan perdagangan biasanya memutar, berangkat dari dataran Tiongkok, menyusuri pesisir Indo Cina, Thailand, Semenanjung Melayu, lalu Tumasik (Singapura), sampai di sini rute perjalanan dibagi menjadi 2 yaitu: menuju Asia Tengah dan ke arah Selatan, rute ke Selatan akan menyusuri pulau Sumatera dan Madura, rute perjalanan pulang bertolak dari ujung Timur pulau Jawa, menyeberangi laut Jawa, Selat Karimata, menyusuri Kalimantan Barat, Brunei, menyeberang ke Palawan, dan Taiwan kemudian kembali ke daratan Tiongkok (Nor Huda, 2017: 2). 
Pada abad ke-1 M telah ada Para pedagang Tionghoa di Palembang. Dengan ditemukannya keram ik Han (206 SM- 219 M) di Kerinci dan Hulu Sungai Musi merupakan bukti bahwa hubungan Tionghoa dengan masyarakat Melayu Palembang sudah terjalin jauh sebelum pengaruh India di Nusantara. Dibawah pimpinan Laksamana Haji Sam Po Bo (Beng Ho) dari Dinasti Ming pada tahun 809 H/ 1407 $\mathrm{M}$, armada kerajaan Tionghoa merebut Kukang (Palembang) yang pada saat itu dikuasai oleh orang Tionghoa non-muslim. Di sana mereka membentuk komunitas Tionghoa Islam pertama di Nusantara. Setelah itu mendirikan komunitas Tionghoa Islam di Sambas, Kalimantan Barat, Semenanjung Malaka, Pulau Jawa dan Philipina secara bertahap (Zulkifli Abdul Karim, 2001:4-6).

Sebagian besar orang Tionghoa datang ke wilayah nusantara mengelompok berdasar kesamaan suku tempat asalnya di Tiongkok. Jika di Jawa dan sebagian Sumatera didominasi oleh kelompok Hokkien dan Kanton. Menurut I Tsing, etnis Tionghoa Muslim telah terdapat di Kedatuan Sriwijaya yang dibawa oleh orang Tionghoa Muslim yang berasal dari Mainland Tiongkok. I Tsing merupakan pendeta dan pelajar dari Tiongkok yang berlabuh di Sribusa (Sriwijaya) pada tahun $671 \mathrm{M}$, la telah mencatat kehadiran etnis Tionghoa Muslim di Palembang (Any Rahmayani, 2014: 17).

Pada abad ke-12 dan ke-13 yang merupakan masa awal kedatangan Islam, Sriwijaya yang merupakan pusat kekuasaan Budha saat itu telah mulai menunjukkan tanda-tanda kehancuran. Sementara itu, pada abad ke-14 Kaisar Yung Lo dari Dinasti Ming telah mempergunakan kesempatan yang baik karena di daerah Selatan sedang mengalami kekosongan kekuasaan dan merajalelanya perom pak-perompak di perairan laut Tiongkok Selatan. Kaisar Ming mengirimkan suatu ekspedisi yang dipimpin oleh orang-orang Tionghoa muslim berasal dari Yunan yaitu Laksamana Ceng Ho (Sebastian Atmodjo, 2017:20).

Salah satu kota bandar yang pernah dikunjungi oleharmada Ceng Ho, adalah Palembang yang telah ada agama Islam. Tempat-tempat yang pernah dikunjungi, biasanya ditempatkan seorang pemuka Tionghoa muslim yang berfungsi ganda. Di samping meletakkan hubungan politik Tiongkok dengan daerah setem pat, juga mem berikan 
hadiah-hadiah yang cukup menarik kepada penghulu kota-bandar. Hadiah yang diberikan itu tidak hanya mengandung latar belakang politik-ekonomi saja, tetapi lebih daripada itu untuk menulari keluarga istana menjadi orang muslim (Hamka, 2017: 534).

Tradisi orang Tionghoa memberikan hadiah berupa putra-putn Tionghoa muslim (peranakan) kepada penguasa bandar, nampaknya tidak hanya di daerah ini, akan tetapi berlaku juga di kalangan masyarakat tertentu, akulturasi antara putri Tionghoa dengan orang biasa pun kemungkinan itu bisa terjadi. Seperti di Pulau Kemaro yang kini menjadi pusat persembahyangan orang-orang TionghoaKonghucu pada hari besar (Cap Go Me), tempat tersebut adalah kuburan orang Tionghoa Muslim. Demikian pula kuburan para raja-raja Palembang di Lemabang dan Sabokingking yang terletak di Kampung Dua Ilir, ditemukannya makam putri Tionghoa di samping permaisuri raja. Putri Tionghoa (Putri Kian) adalah Seorang gadis Tionghoa Muslim yang menetap di Kuto Gawang, Putri Kian menikah dengan Ario Damar-putra Prabu Kertabumi Brawijaya V-yang menjadi pemimpin Palembang.

Adanya perkawinan orang-orang Tionghoa dengan penduduk setempat, ketika Ceng Ho mengunjungi Samudra Pasai. Bukan hal yang tidak mungkin apabila tradisi serupa dilakukan pula oleh Ceng Ho di Palembang pada awal abad ke-15 yang telah menyebarkan agama Islam di kalangan keluarga Istana dan terjadi fenomena kultural, penyebaran agama Islam seperti itu, harus dipandang sebagai suatu cara pendekatan melalui jalan diplomasi, yang pernah dilakukan pula oleh orang-orang asing muslim lainya terhadap putri-putri penguasa Bandar (K.H.O. Gadjahnata dan Sri-Edi Swasono, 1986: 13).

Migrasi orang Tionghoa ke Nusantara terjadi sejak ratusan tahun lalu (206 SM-219 M). Melalui perjalanan sejarah yang panjang, migrasi ini terserap dalam arus dinamika perjalanan bangsa. Sejak kedatangan mereka pertama kali dan diikuti para imigran Tionghoa gelombang kedua, migrasi ini tak jarang menimbulkan berbagai permasalahan. Ketika Indonesia memasuki masa kem erdekaan, permasalahan migran Tionghoa bertalian kuat dengan identitas mereka sebagai migran dari luar kelompok Indonesia, atau sebagai bangsa asing. Tekanan ekonomi dalam negara Tiongkok telah memaksa orang Tionghoa merantau ke Asia Tenggara. Faktor kemiskinan menjadi salah satu 
penyebab orang-orang Tionghoa berimigrasi ke Asia Tenggara. Di samping itu, keadaan politik dalam negeri seperti Perang Candu 1839, Pemberontakan Taiping $1851 \mathrm{M}$, serta krisis ekonomi yang terjadi berulang kali seperti wabah kelaparan akibat kegagalan panen telah mendorong ribuan im igran dari Tiongkok Selatan mencari pekerjaan ke luar wilayahnya (Peter Cerey, 1985: 65).

\section{TEORI DAN METODOLOGI}

Dalam penelitian ini, untuk memperkuat analisis, penulis akan menggunakan Teori Peranan (Role Theory) dari Levinson, teori ini untuk melihat kedudukan Peran Etnis Tionghoa Muslim pada masa Kolonial Belanda abad ke-19 di Palembang. Dalam teori sosiologi terdapat teori tentang sistem lapisan masyarakat yang mempunyai dua unsur pokok yaitu kedudukan dan peranan. Peranan (Role) merupakan proses dinamis kedudukan (status). Apabila seseorang melaksanakan hak dan kewajibannya sesuai dengan kedudukannya, dia menjalankan suatu peran. Perbedaan antara kedudukan dengan perananan adalah untuk kepentingan ilmu pengetahuan. Keduanya tidak dapat dipisahpisahkan karena yang satu tergantung pada yang lain dan sebaliknya, kedua unsur ini tidak dapat dipisahkan. Tidak ada peranan tanpa kedudukan atau sebaliknya tidak ada kedudukan tanpa peranan.

Metode dalam Penelitian ini menggunakan metode kepustakaan (library research), karena cara mengumpulkan data melalui peninggalan tertulis terutama berupa arsip-arsip dan termasuk juga buku-buku tentang pendapat, teori, dan lain-lain yang berhubungan dengan masalah penelitian. Penulis untuk mencari data mengunjungi berbagai perpustakaan seperti perpustakaan Pusat UIN Raden Fatah Palembang, Perpustakaan Adab dan Humaniora UIN Raden Fatah Palembang, Perpustakaan Daerah Palembang, Perpustakaan Nasional Republik Indonesia, Arsip Nasional Republik Indonesia Serta perpustakaan pribadi milik Andi Syarifuddin di rumahnya di depan Masjid Agung Palembang. Penulis berusaha mengumpulkan bukubuku atau bahan-bahan sebagai pedoman dan mereview buku dengan cara membedah isi buku yang terkait dengan penelitian ini.

Sedangkan pendekatan yang digunakan penulis menggunakan pendekatan struktural-fungsional oleh Tallcot Persons dan 
pengikutnya, dipakai untuk mengetahui sejauh mana interaksi sosial antaretnis (mayoritas dan minoritas) dan kemungkinan terjadinya integrasi. Perlu dikemukakan bahwa fungsionalisme struktural pertama kali muncul dengan cara pandang dimana masyarakat dilihat sebagai organisme biologis, suatu pendekatan yang sering dinamakan organismic approach.

Pendekatan struktural-fungsional sebagaimana dikembangkan oleh Parsons dan pengikutnya memiliki sejumlah anggapan dasar, yakni: Pertama, masyarakat harus dianalisis secara totalitas, sesuatu sistem yang terdiri dari sejumlah bagian yang saling berhubungan; kedua, hubungan sebab-akibat atau saling mempengaruhi di antara bagian-bagian itu adalah bersifat ganda dan timbal-balik; ketiga, meskipun integrasi sosial tidak pernah terwujud dengan sempurna, tetapi secara fundamental sistem sosial selalu cenderung menuju equilibrium yang dinamis; merespons peubahan-perubahan yang terjadi dalam sistem sebagai akibatnya hanya akan mencapai derajat yang minimal.

Selanjutnya, struktural fungsional berpandangan bahwa adanya komitmen terhadap norma-norma sosial (nilai-nilai bersama) sangat penting terjadinya integrasi dalam suatu masyarakat. Sehingga, dapat dikatakan bahwa individu-individu dan kelompok-kelompok manusia akan terintegrasi bila adanya, antara lain, persamaan kepentingan(interest), keyakinan (agama) dan status sosial. Kaitannya dengan topik skripsi saya ialah sejauh mana integrasi antara Etnis Tionghoa Muslim dengan masyarakat Melayu Palembang.

Adapun sumber data yang digunakan dalam penelitian ini adalah: 1) Sumber data Primer atau data pokok, yaitu: data yang diperoleh langsung dari subyek penelitian dengan menggunakan teknik wawancara dan melihat teks naskah. Dalam hal ini peneliti mewawancarai Azim Amin, Herwansyah, Nor Huda Ali sebagai ahli bidang Peran Masyarakat Tionghoa Muslim di Palembang;2) Sumber Data Sekunder adalah sumber pendukung, yaitu: data yang diperoleh dari lewat pihak lain tidak langsung diperoleh oleh peneliti dari subyek penelitiannya diantaranya adalah "Peranan Tarekat Tsamaniyyah dalam melawanKolonial Penjajahtesis Raudatul Jannah Pascasarjana Uin Raden Fatah Palembang, serta tesis Abd. Azim Amin "Corak 
Pemikiran Tasawuf Baba Abdullah"; dan 3) Jurnal, Majalah dan artikel yang relevan dengan judul diatas.

\section{PEMBAHASAN}

Pada abad ke-7 M di Palembang, Islam telah ada pada masa kerajaan Sriwijaya. Adanya komunitas Tionghoa Muslim di Sriwijayamerupakan titik awal penyebaran Islam ke berbagai pelosok tanah air. Mengingat, Islam sebenarnya bukanlah sesuatu agama yang baru bagi masyarakat Tionghoa. Pada tahun 809 H/1407 M di bawah pimpinan Laksamana Haji Sam Po Bo (Beng Ho) dari Dinasti Ming, armada kerajaan Tionghoa merebutKukang (Palembang) yang pada waktu itu dikuasai oleh orang Tionghoa non-muslim. Di sana mereka membentuk suatu komunitas etnis Tionghoa Islam pertama di Nusantara. Setelah itu secara bertahap mendirikan komunitas Tionghoa Islam di Sambas, Kalimantan Barat, Semenanjung Malaka, Pulau Jawa dan Philipina (Liang Liji, 2012: 248).

Sebagian besar orang Tionghoa datang ke wilayah Nusantara secara berkelompok. Jika di Jawa dan sebagian Sumatera didominasi oleh kelompok Hokkien dan kanton. Menurut I Tsing, komunitas Tionghoa Muslim pun telah terdapat pada kerajaan Sriwijaya yang di kembangkan oleh orang Tionghoa Muslim asal Mainland Tiongkok (Any Rahmayani, 2014: 17). Migrasi orang Tionghoa ke Indonesia (Nusantara) terjadi sejak ratusan tahun lalu. Melalui perjalanan sejarah yang panjang, migrasi ini terserap dalam arus dinamika perjalanan bangsa. Sejak kedatangan mereka pertama kali dan diikuti para imigran Tionghoa gelombang kedua, migrasi ini tak jarang menimbulkan berbagai permasalahan. Ketika Indonesia memasuki masa kemerdekaan, permasalahan migran Tionghoa bertalian kuat dengan identitas mereka sebagai migran dari luar kelompok Indonesia, atau sebagai bangsa asing (Abdullah Idi, 2006: 13).

Pada masa Kesultanan Palembang orang-orang Tionghoa tidak diperbolehkan memiliki lahan pertanian, mereka diperkenankan tinggal di atas perahu yang disebut rumah rakit di Sungai Musi. Kebijakan ini diambil oleh Sultan dengan maksud melindungi kepentingan kerajaan serta memudahkan pihak kesultanan untuk mengendalikan orangorang Tionghoa, yakni dengan cara membakar rumah rakit mereka 
kalau dipandang keberadaan orang Tionghoa membahayakan. Orangorang Tionghoa yang dimaksudialah orang-orang Tionghoa beragama Konghucu, Nasrani, Sedangkan Etnis Tionghoa Muslim Peranakan Sudah dianggap sebagai bagian dari pribumi (Van Sevenhoven, 2015: 15).

Kondisi Etnis Tionghoa Muslim pada masa Kesultanan Palembang jauh lebih baik dari Etnis Tionghoa yang beragama lain, contohnya pada saat kepimpinan Sultan Mahmud Bahauddin dan Sultan Mahmud Badaruddin II, Etnis Tionghoa berperan sebagai Menteri Kerajaan salah satunya Kiyai Mas Husin (Yu-Chien) sebagai bendahara kerajaan dan perancang pembangunan kota kerajaan (1740 M/ $1153 \mathrm{H}$ ), Baba Yu-Chien kemudian memiliki anak bernama Muham mad Najib I yang bergelar Kiyai Demang Jayosepuh Wiraguno yang menjabat sebagai menteri pada masa Sultan Ahmad Najamuddin, Baba Muhammad Najib I mempunyai seorang Putera bernama Baba Abdul Khalik, Beliau menjabat sebagai Tiku padamasa Sultan Mahmud Badaruddin I yang diberi gelar Kiyai Demang Wiralaksono, setelah beliau wafat digantikanlah oleh anak beliau yang bernama Baba Balqiyah dan Baba Mas'ud, mereka ikut berperan dalam melawan Kolonial Belanda dan menenggelamkan kapal pesiar milik Belanda di Muara Sungai Ogan Palembang. Setelah mereka meninggal digantikanlah perannya oleh Baba Muhammad Najib II atau Kiyai Demang Jayalaksana yang merupakan tokoh penting dalam pembangunan masjid Agung Palembang di masa Sultan Mahmud Badaruddin II (1724 M/ $1137 \mathrm{H}$ ) beliau memotori pencetakan Al-Quran secara Massal. Tujuannya untuk menjaga jati diri bangsa Melayu yang mayoritas Islam dari bangsa penjajah Belanda.

Pada masa kedatangan penjajah Belanda, masyarakat Palembang sengaja dibentuk menjadi masyarakat yang disintegrasi melalui strategi politik "devide et impera" (adu domba). Pada tahun $1270 \mathrm{H} / 1854 \mathrm{M}$ Belanda menetapkan masyarakat pribumi sebagai kelas terendah (inlander) setelah dua kelompok Eropa sebagai kelas satu dan Timur Asing (misalnya Tionghoa, India, Arab) sebagai kelas dua. Pengelompokan masyarakat Hindia Belanda tersebut diyakini sebagai penyebab utama adanya keretakan hubungan antara etnis Tionghoa dengan kalangan pribumi. Wujud dari tindakan diskriminatif 
tersebut, Belanda yang menjajah Nusantara, telah menciptakan suatu sistem sosial, politik, dan ekonomi yang diskriminatif. Bagi bangsa pribumi, tindakan diskriminatif penjajah serta konsekuensi-konsekuensi yang harus dihadapi kemudian menumbuhkan benih-benih kecemburuan dan kebencian kalangan pribumi terhadap etnis Tionghoa, tujuan pemerintah Kolonial Belanda adalah agar orang Tionghoa tidak terlalu dekat dengan Pribumi dan tidak menjadi pesaingnya, melainkan untuk dijadikan pelaku dagang yang menguntungkan Belanda (Jumhari, 2006:3).

Pada masa Kolonial Belanda, para pedagang Tionghoa memegang peranan penting dalam perekonomian di Palembang. Bahkan usaha Kolonial untuk memonopoli pun terham bat dan mereka terpaksa berbisnis dengan para pedagang Tionghoa tersebut. Akibatnya, Kolonial Belanda merasa terancam karena keberadaan etnis Tionghoa secara tidak langsung menyokong kehidupan pribumi di Palembang, dan jika etnis Tionghoa dan pribumi bersatu untuk melawan Kolonial Belanda akan kewalahan. Karena itulah, Kolonial Belanda mengadu domba pribumi dan etnis Tionghoa. Kondisi ini semakin kokoh dengan adanya pengelompokkan hunian (pemukiman) berdasarkan kelompok etnik tertentu, maka di kota-kota besar di Indonesia pada masa Kolonial seperti Batavia, Semarang termasuk pula Palembang dijumpai kampung-kampung kategoritersebut, sepert kampung Kapiten, kampung Arab, kam pung Jawa, kampung Bugis dan kampung etnik lainnya, yang mencerminkan pemisahan secara fisik.

Saat ini, posisi etnis Tionghoa Muslim Palembang dalam masyarakat dapat dikatakan tidak mengalami hambatan yang berarti, memang pada awalnya beberapa dari mereka mengalami sedikit kendala dalam menjalani hubungan dengan orang-orang sekitar. Namun seiring dengan berjalannya waktu, hubungan mereka kembali menjadi baik seperti biasa. Keadaan ini menunjukkan kecenderungan masyarakat Palembangyang toleran dalam mengayomi etnis Tionghoa di Palembang yang memeluk agama Islam.

Di Palembang cukup banyak Ulama keturunan Etnis Tionghoa yang berperan menyebarkan agama Islam maupun melawan penjajahan, termasuk tokoh-tokoh cendekiawan dan pengusaha Tionghoa, Peranan mereka dalam pengembangan Islam di Palembang 
kurang dikenal oleh masyarakat luas, meskipun di antara mereka banyak yang menulis atau berjuang melawan Kolonial Belanda. Mereka juga kurang mendapat tempat dalam historiografi Islam di Palembang, sehingga gambaran sejarah dan peranan orang-orang Tionghoa Muslim di Palembang tidak utuh. Harus diakui bahwa etnis Tionghoa tidak selalu berwajah Budha atau Konghucu saja akan tetapi juga ada Tionghoa yang berwajah Islam dan tentunya memiliki peran penting dalam penyebaran agama Islam juga mempertahankan wilayah Palembang dari Kolonial Belanda (Onghokham, 2009: 131).

Pada masa Kolonial Belanda populasi Etnis Tionghoa Muslim terus meningkat dan memainkan peran penting di masa Kesultanan Palembang, cukup banyak Ulama keturunan Etnis Tionghoa yang berperan menyebarkan agama Islam maupun melawan penjajahan, termasuk tokoh-tokoh cendekiawan dan para ulama, akan tetapi peranan mereka dalam pengembangan Islam di Palembang kurang dikenal oleh masyarakat luas, meskipun di antara mereka banyak yang menulis karya-karya kitab atau berjuang melawan Kolonial Belanda. Yang dimaksud dengan sebutan kyai atau ulama dalam penelitian ini adalah mereka yang mempunyai keahlian dalam bidang keilmuan Islam dan dengan konsisten mengamalkan ilmunya itu, sehingga mendapat pengakuan dari masyarakat Muslim secara luas. Untuk melihat dinamika sejarah sosial intelektual Islam di Palembang dengan mengambil rentang waktu pada abad ke-19 hingga abad ke-20 tepatnya pada masa Kolonial Belanda. Di dalam sejarah sosial intelektual Islam di Palembang, ternyata ulama-ulama tidak hanya berasal dari kalangan birokrat yang bersifat mengikat, ada juga ulamaulama besar di Palembang ini berasal dari masyarakat kebanyakan. Mereka ini sering disebut dengan "ulama bebas" atau ulama independen. Bahkan, diantara mereka bukan hanya berasal dari kalangan suku Melayu-Palembang. Para ulama ini juga banyak yang berasal dari keturunan Tionghoa (Nor Huda, 2017: 8). 


\section{KESIMPULAN}

Berdasarkan pada pembahasan yang telah dipaparkan semua, penulis menyimpulkan beberapa argumen bahwa di Palembang cukup banyak Ulama keturunan Etnis Tionghoa yang berperan menyebarkan agama Islam maupun melawan penjajahan, termasuk tokoh-tokoh cendekiawan dan pengusaha Tionghoa, Peranan mereka dalam pengembangan Islam di Palembang kurang dikenal oleh masyarakat luas, meskipun di antara mereka banyak yang menulis atau berjuang melawan Kolonial Belanda. Mereka juga kurang mendapat tempat dalam historiografi Islam di Palembang, sehingga gambaran sejarah dan peranan orang-orang Tionghoa Muslim di Palembang tidak utuh.

Saat ini, posisi etnis Tionghoa Muslim Palembang dalam masyarakat dapat dikatakan tidak mengalami hambatan yang berarti, memang pada awalnya beberapa dari mereka mengalami sedikit kendala dalam menjalani hubungan dengan orang-orang sekitar. Namun seiring dengan berjalannya waktu, hubungan mereka kembali menjadi baik seperti biasa. Keadaan ini menunjukkan kecenderungan masyarakatPalembangyang toleran dalam mengayomi etnis Tionghoa di Palembang yang memeluk agama Islam. Harus diakui bahwa etnis Tionghoa tidak selalu berwajah Budha atau Konghucu saja akan tetapi juga ada Tionghoa yang berwajah Islam dan tentunya memiliki peran penting dalam penyebaran agama Islam juga mempertahankan wilayah Palembang dari Kolonial Belanda.

\section{REFERENCES}

Abdul Karim, Zulkifli, 2001. Islam dalam Sejarah dan Budaya Masyarakat Sumatera Selatan, Sumatera Selatan: Universitas Sriwijaya.

Afif, Afthonul, 2012. Identitas Tionghoa Muslim Indonesia, Jawa Barat Kepik.

Atmodjo, Sebastian, 2017. Laksamana Ceng Ho Jejak Damai Penjelajah Dunia, Yogyakarta: Sociality. 
Vol. 1, No. 1, Juni 2021: h.66-77. DOI: xxxxxx/jih.v1i1.\{\}

Cerey, Peter, 1985. Orang Jawa dan Masyarakat Cina 1755-1825, Jakarta: Pustaka Azet.

Gadjahnata, K.H.O, 1986. Masuk dan Berkembangnya Islam di Sumatera Selatan, Jakarta: Universitas Indonesia.

Hamka, 2017. Sejarah Umat Islam Pra-Kenabian Hingga Islam di Nusantara, Jakarta: Gema Insani.

Huda, Nor, 2017. Orang-Orang Cina dan Perkembangan Islam di Palembang, Palembang: Nur Fikri.

Idi, Abdullah, 2006. Sejarah Sosial Cina dan Melayu, Yogyakarta: ArRuzz Media.

Imran, Mahmud, Kiagus, 2004. Sejarah Palembang, Palembang: Anggrek Palembang.

Jumhari, 2010. Sejarah Sosial Orang Melayu, Keturunan Arab dan Cina di Palembang, Padang:BPNST Padang Press.

Liji, Liang, 2012. Dari Upeti ke Mitra Strategis: 2.000 Tahun Perjalanan Hubungan Tiongkok-Indonesia, Jakarta: PT Kompas Media Nusantara.

Onghokham, 2009. Riwayat Tionghoa Peranakan di Jawa, Jakarta: Komunitas Bambu.

Rahmayani, Any. 2014. Pemukiman Orang Tionghoa di Singkawang, Yogyakarta: Ombak.

Sevenhoven, Van, 2015. Lukisan Tentang lbu kota Palembang, Yogyakarta: Ombak. 